\title{
RE-THINKING THE FAIR WORK PROTECTION AGAINST DISCRIMINATORY DISMISSAL
}

\author{
JOELLEN RILEY
}

\section{ABSTRACT}

People who lose their jobs as a consequence of discriminatory treatment at work face an array of options for redress. They might bring proceedings for unfair dismissal before a statutory tribunal (the Fair Work Commission), or they may pursue a claim in the Federal Court of Australia. This article contemplates the possibility that the system for dealing with discriminatory dismissal could be rationalized so that aggrieved employees might have a single, accessible pathway through an administrative process to deal with such complaints. This would involve rethinking whether discrimination complaints ought to be treated as a matter of vindicating legal rights, or as a matter of arbitrating competing interests. Abandoning the language of rights may facilitate a pathway around the Boilermakers' doctrine (which mandates that only courts can determine legal rights), and so enable the establishment of a more accessible and effective avenue for dealing with discrimination at work.

An employee who has been dismissed from her job for discriminatory reasons - let's say it is because, as the mother of an infant, she doesn't attend enough of the firm's social functions held out-of-hours - would have two avenues for complaint under the Fair Work Act 2009 (Cth). ㄴ. She might make an application under Pt 3-2 'Unfair Dismissal', alleging that she has been dismissed
Formatted: Left

Formatted: Font: Italic

${ }^{1}$ Dean and Professor of Labour Law, Sydney Law School. I would like to thank my colleague, Dr Belinda Smith, for detailed comments on the manuscript for this article, and for the benefit of many years of discussions with her on matters of equality and discrimination law. I would also like to thank Therese MacDermott, my collaborator on a number of projects on dispute resolution, for her advice and comments. They are both innocent of any errors remaining in this article, and the views expressed are my own.

${ }^{2}$ She might also make a complaint under a state or federal discrimination statute, but those options are not considered in this article. 
without a valid reason, in circumstances that are 'harsh, unjust or unreasonable'. ${ }^{3}$ Or she might pursue a complaint under Pt 3-1 'General Protections' on the basis that her dismissal constitutes 'adverse action' taken against her 'because of' her family or carer's responsibilities. ${ }^{4}$ Both options are available to an employee who falls within the scope of the unfair dismissal protections. So employees whose work is covered by a modern award or enterprise agreement, ${ }^{5}$ or who earn below the high income threshold, ${ }^{6}$ and who have served the minimum employment period, ${ }^{7}$ can choose between these two avenues, if they wish to challenge their dismissal.

Depending on which path such an employee chooses, the process for dealing with the matter will be very different. ${ }^{8}$ If she proceeds as an unfair dismissal applicant, she must lodge an application with Fair Work Australia within 14 days after the dismissal took effect, ${ }^{9}$ and Fair Work Australia will arrange a compulsory private conference between the employee and the employer to seek to resolve the dispute. ${ }^{10} \mathrm{It}$ is most likely that this conference will be held by telephone, and conducted by a mediator employed by Fair Work Australia. ${ }^{11}$ If the matter is not resolved at this stage, a member of Fair Work Australia is empowered to arbitrate the matter, with a view to ensuring that 'a "fair go all round" is accorded to both the employer and employee concerned' ${ }^{12}$ The whole process can be over in a matter of weeks, at very little cost to the applicant (especially if she has not engaged any legal representation).

\footnotetext{
${ }^{3}$ Fair Work Act s 385. For commentary on the unfair dismissal laws see Anna Chapman 'The Decline and Restoration of Unfair Dismissal Rights' in Anthony Forsyth and Andrew Stewart (eds) Fair Work: the New Workplace Laws and the Work Choices Legacy (2009), 207-228.

${ }^{4}$ Fair Work Act s 351. For a note on early adverse action cases, see Joellen Riley 'Adverse Actions Claims under the Fair Work Act 2009 (Cth): Some Lessons from the Early Cases' [2011] Sep-Nov Commercial Law Quarterly 12.

${ }^{5}$ Fair Work Act s 382(b)(i) and (ii).

${ }^{6}$ Fair Work Act s 382(b)(iii) and Fair work Regulations Reg 3.05. At the time of writing the high income threshold was $\$ 123,300$ (from I July 2012). This amount is indexed annually.

${ }^{7}$ Fair Work Act s 383. This period is six months, or 12 months if the employer is a 'small business employer', defined in $\mathrm{s} 23$ as one who employs fewer than 15 employees.

${ }^{8}$ For a fuller account of the procedures for pursuing each type of claim, see Therese MacDermott and Joellen Riley 'ADR and Industrial Tribunals: Innovations and Challenges in Resolving Individual Workplace Grievances' (2012) 38(2) Monash University Law Review_??? (forthcoming).

${ }^{9}$ Fair Work Australia can grant an extension of time in 'exceptional circumstances': see Fair Work Act s 366(2).

${ }^{10}$ Fair Work Act ss 365 and 368(1).

${ }^{11}$ See Jenny Acton 'Fair Work Australia: An Accessible, Independent Umpire for Employment Matters' (2011) 53(5) Journal of Industrial Law 578-595. See also TNSSR Consultants Fair Work Australia Unfair Dismissal Results, November 2010 for data on the operation of the telephone conferencing system.

${ }^{12}$ Fair Work Act s 381(2).
} 
If she chooses instead to pursue a 'general protections' claim, and the matter is not resolved in the private conference held by a Fair Work Australia member, ${ }^{13}$ she must commence proceedings in the federal court system to take her complaint any further. The matter is unlikely to be heard within nine months, and is likely to cost each party many tens of thousands of dollars in legal fees. The court will decide her complaint as a matter of law, and she will either win or lose. Even if she wins, there is little chance of recovering her legal costs, because costs are generally not awarded in matters brought under the Fair Work Act. ${ }^{14}$

The procedural differences in these two avenues for complaint are a consequence of the doctrine of separation of powers in Australian constitutional law. ${ }^{15}$ The unfair dismissal complaint is conceived as an interests dispute, appropriately resolved by an administrative decision-maker, while the general protections claim is treated as an assertion of a legal right which must be determined by a judge in a court of law. ${ }^{16}$ The first avenue leads the complainant to a tribunal exercising administrative power; the second to a court exercising judicial power.

Need it necessarily be so? Must we retain this bifurcation between 'unfair' and 'unlawful' dismissals, ${ }^{17}$ which dictates more onerous legal procedures for dealing with discriminatory dismissal than those permitted for sanctioning merely capricious ones? This paper investigates the scope for an alternative construction of the protections against discriminatory dismissals in the Fair Work Act, so that these kinds of complaints could also be dealt with by the more accessible dispute resolution means available to unfair dismissal complainants. At the core of

${ }^{13}$ See Fair Work Act s 368 which requires Fair Work Australia to conduct a conference to deal with any general protections dispute involving dismissal.

${ }^{14}$ See Fair Work Act s 570(2). The decision to award costs in Ashby v Commonwealth of Australia (No 4) was unusual, and based on peculiar circumstances: see [2012] FCA 1411, [200]-[202].

${ }^{15}$ See $R$ v Kirby; Ex parte Boilermakers' Society of Australia (1956) 94 CLR 254 ('Boilermakers'), affirmed in AttorneyGeneral of the Commonwealth of Australia v R [1957] AC 288 (PC). For commentary see G Sawer, 'The Separation of Powers in Australian Federalism' (1961) 35 Australian Law Journal 177; Fiona Wheeler 'Original Intent and the Doctrine of the Separation of Powers in Australia' (1996) 7 Public law Review 96.

${ }^{16}$ See Rosemary Owens, Joellen Riley and Jill Murray, The Law of Work, $2^{\text {nd }}$ ed, (2011), 622-624; Therese MacDermott and Joellen Riley 'Alternative Dispute Resolution and Individual Workplace Rights' (2011) 53(5) Journal of Industrial Relations 718, 722-724.

17 The former Workplace Relations Act 1996 (Cth) used the terminology of 'unlawful' termination for the kinds of discriminatory dismissals which would now offend the General Protections provisions in Pt 3-1 of the Fair Work Act. For commentary on the Workplace Relations Act provisions, see Anna Chapman 'Termination of Employment under the Workplace Relations Act 1996 (Cth)' (1997) 10(1) Australian Journal of Labour Law 89; Therese MacDermott 'Industrial Legislation in 1996: The Reform Agenda' (1997) 39(1) Journal Ofof Industrial Law 52, 63-4. 
this proposed new construction is a controversial proposition: that the general protections provisions in the Fair Work Act ought not to be framed as legal protections for absolute 'human rights', but ought - like the unfair dismissal provisions - be framed as guarantees of a 'fair go all round' for workplace participants. ${ }^{18}$

This argument runs against the contemporary wisdom that asserts that labour rights, and particularly individual worker's rights to non-discriminatory treatment, are human rights and should be protected as such by law. ${ }^{19}$ As incontrovertible as this assertion is, in the Australian legal system, it leads away from the most accessible form of dispute resolution for workers whose rights have been compromised, and it leaves them in the hands of the courts, which (with respect) have a poor record for enforcing anti-discrimination laws in any event.

An emerging literature on the role of courts in interpreting and applying discrimination statutes criticizes court enforcement as ineffective in meeting the policy objectives of this kind of remedial legislation..$^{20}$ Professor Beth Gaze has written that it is 'rare for judges to consider the policy concepts underpinning these laws' when interpreting and applying them. ${ }^{21}$ There are a number of views on why this may be so. The role of courts in determining hard rights, after an allegation of some infringement, may inhibit courts from making decisions promoting the broad remedial purposes of these laws. ${ }^{22}$ Professor Judy Fudge has suggested that a reason for this may be that judges are concerned that they lack the legitimacy to make determinations about equality when these decisions may have budgetary

\footnotetext{
${ }^{18}$ See Fair Work Act s 381(2). This expression originated in the New South Wales jurisdiction when used by Sheldon $J$ in In Re Loty and Holloway v Australian Workers' Union [1971] AR (NSW) 95, a case in which an industrial tribunal weighed the interests of both employer and employees in deciding whether to order reinstatement as part of the settlement of an industrial dispute.

${ }^{19}$ See for example Philip Alston (ed) Labour Rights as Human Rights (2005).

${ }^{20}$ See generally Margaret Thornton, 'Sex Discrimination, Courts and Corporate Power' (2008) 36 Federal Law Review 31; Margaret Thornton, 'Disabling Discrimination Legislation: The High Court and Judicial Activism' (2009) 15 Australian Journal of Human Rights 1; Belinda Smith 'From Wardley to Purvis - How Far has Australian AntiDiscrimination Law Come in 30 Years?' (2008) 21 Australian Journal of Labour Law 3; Beth Gaze, 'Context and Interpretation in Anti-discrimination Law' (2002) 26 Melbourne University Law Review 325.

${ }^{21}$ See Beth Gaze 'Context and Interpretation in Anti-discrimination Law' (2002) 26 Melbourne University Law Review 325, 332.

22 See Gaze above n2119, 333; Susan Sturm 'Law, Norms, and Complex Discrimination' in Brian Bercusson and Cynthia Estland (eds) Regulating Labour in the Wake of Globalisation: New Challenges, New Institutions (2008): Belinda Smith 'Rethinking the Sex Discrimination Act: Does Canada's Experience Suggest we should give our Judges a Greater Role?' in Margaret Thornton (ed) Sex Discrimination in Uncertain Times, 2008.
}

Formatted: Font: $10 \mathrm{pt}$, Italic
Formatted: Font: $10 \mathrm{pt}$, Italic
Formatted: Font: $10 \mathrm{pt}$, Italic
Formatted: Font: $10 \mathrm{pt}$, Italic
Formatted: Font: $10 \mathrm{pt}$, Italic


implications for the executive branch of government. ${ }^{23}$ Whatever the reasons, court enforcement of discrimination law has been disappointing to the discrimination law scholars. I aAccordingAccording to Dr Belinda Smith: 'Apart from a few initial progressive judgments, the courts have struggled to give anti-discrimination laws the wide and generous interpretation supposedly granted to beneficial legislation. ${ }^{24} \mathrm{~A}$ more pragmatic approach if we want to ensure better respect for these principles would be to frame them in a way which permits these claims to be dealt with more informally, by administrative rather than legal process. This pragmatism has some philosophical support. Belinda Smith makes a powerful argument (drawing also on the work of Nancy Fraser and Sandra Fredman) that the interdependence of socioeconomic and status-based inequality in society justifies a common regulatory framework for addressing statusbased inequality and claims for redistributive justice. ${ }^{25}$ 'Maintaining separate regulatory frameworks allows for complexity, uncertainty and inconsistency' and 'can undermine effectiveness' ${ }^{26}$ In short, there is no good reason why capricious and discriminatory dismissals should be regulated differently, and every reason that they should be managed by the same institution that deals with other questions of workplace justice.

There are various options that might be investigated in finding a single regulatory framework for consolidating all employment dismissal disputes. One would be to treat all cases as matters of the enforcement of workplace rights (including a right to job security protected from capricious dismissal), and to establish small claims courts to deal with those matters. The challenge for such a proposal would be ensuring that the most impecunious claimants had access to appropriate legal advice (possibly through an extension of legal aid services or governmentfunding of a network of community legal centres experienced in workplace law). The option examined in this paper is that the existing institution (FWA) should also manage discriminatory

\footnotetext{
${ }^{23}$ See Judy Fudge 'Substantive Equality, the Supreme Court of Canada, and the Limits to Redistribution' (2007) 23 South African Journal on Human Rights 235.

${ }^{24}$ Belinda Smith, 'What Kind of Equality Can We Expect from the Fair Work Act?' (2011) 35(3) Melbourne University Law Review 545, 563. See also Margaret Thornton, 'Disabling Discrimination Legislation: the High Court and Judicial Activism' (2009) 15 Australian Journal of Human Rights 1.

${ }^{25}$ See Smith above $\mathrm{n} 2419,567$, citing Sandra Fredman, 'Recognition or Redistribution: Reconciling Inequalities' (2007) 23(1) South African Journal of Human Rights 214, and Nancy Fraser, Justice Interruptus: Critical Reflections on the "Postsocialist" Condition (1997) 13.

${ }^{26}$ Smith above $\mathrm{n}$ 2419, 576.
} 
dismissal claims though to completion. Views on these options and others will be varied, and it is not the intention of this article to canvass and assess all options. The focus here is to propose how we might overcome present constitutional obstacles to enabling FWA to undertake this function. At the time the Fair Work Act was in development, the prospect of a 'one-stop shop' for employment matters was raised, but quickly shot down on the basis that it would be constitutionally impossible to achieve such an objective. This paper examines whether the onestop shop is indeed feasible, after all.

The paper proceeds by a number of steps. First, the size and scope of the problem is described, to justify the basic claim that we need more accessible dispute resolution processes for discriminatory dismissals. Next, the paper explains (briefly) how unfair and discriminatory dismissal complaints have come to fall on opposite sides of the divide created by the Boilermakers' doctrine between administrative and judicial decision-making. The paper then considers an alternative way of viewing discriminatory dismissals, so that regulation of employer conduct can feasibly be treated as a matter appropriate to arbitration by a tribunal. This step in the reasoning involves examining the High Court of Australia's findings in Attorney-General of the Commonwealth of Australia v Alinta Limited (The Takeovers Panel Case). ${ }^{27}$ Although this case concerned a field far removed from discrimination law (the regulation of the conduct of parties in hostile corporate takeovers), it provides some useful lessons in how to frame pragmatic schemes for dealing with the kinds of disputes that cannot wait upon the usual delays and costs of litigation.

The paper concludes with a reflection on the price that is paid by treating certain interests as hard-edged rights. There may be a practical benefit in persuading high-minded principle to give ground to worldly pragmatism. Reframing the right against discriminatory dismissal as an entitlement to arbitration of an interest in non-discriminatory treatment at work may result in more effective recognition of the ideal that workers ought not to be excluded from participation in the labour market on discriminatory grounds.

${ }^{27}$ [2008] HCA 2. 


\section{SCOPE OF THE PROBLEM}

The case-load of disputed terminations of employment in Australia is substantial. The 2010-2011 Annual Report of Fair Work Australia disclosed that the tribunal dealt with 14,897 applications relating to termination of employment during that financial year. Of these, the great majority $(12,301)$ were unfair dismissal claims, brought under Fair Work Act s 394. Applications under s 365 (which deals with dismissals contravening the General Protections) accounted for 1,944 of the complaints. ${ }^{28}$ Applications brought under s 365 can relate to alleged breaches of any of the general protections and not only the protection under $\mathrm{s} 351$ from discrimination on a variety of grounds. ${ }^{29}$ So these 1,944 cases include dismissals of people who have exercised a workplace right (defined in s 341), ${ }^{30}$ engaged in industrial activities (s 346), ${ }^{31}$ or suffered a temporary absence from work for illness or injury (s 352). ${ }^{32}$

FWA presided over the settlement of 83 percent of the unfair dismissal claims. A further 13 percent of the claims settled following conciliation and so did not proceed to arbitration. Only four per cent - or 517 - were arbitrated. Of those, 151 resulted in a finding that the applicant had been dismissed in harsh, unjust or unreasonable circumstances. The success rate in settling the general protections claims however appears much less impressive. Of the 1,944 claims of this nature, FWA issued a certificate in 650 cases (33 per cent), stating that attempts to resolve

\footnotetext{
${ }^{28}$ Applications brought under s 365 can relate to alleged breaches of any of the general protections, including dismissals of a person who has exercised a workplace right (defined in s 341), engaged in industrial activities

${ }^{29}$ These are race, colour, sex, sexual preference, age, physical or mental disability, marital status, family or carer's responsibilities, pregnancy, religion, political opinion, national extraction or social origin: s 351(1). For examples of cases, see Bayford v Maxxia Pty Ltd [2011] FMCA 202 (family responsibilities - application failed); Ucchino v Acorp Pty Ltd [2012] FMCA 9 (pregnancy - application succeeded); Fair Work Ombudsman v Drivecam Pty Ltd [2011] FMCA 600 (physical disability - application succeeded).

${ }^{30}$ For examples of cases brought on the grounds of a breach of a workplace right, see Khiani v ABS [2010] FCA 1059; [2011] FCAFC 109 (right to take sick leave - application failed); Stephens v Australian Postal Corporation [2011] FMCA 448 (right to make claim under safety legislation - application succeeded); Australian Licensed Aircraft Engineers Association v Qantas Pty Ltd \& Anor [2011] FMCA 58 (right to bring a complaint about entitlements under an enterprise bargain - application succeeded), affirmed on appeal in Qantas Airways Limited $v$ Australian Licensed Aircraft Engineers Association [2012] FCAFC 63.

${ }^{31}$ For examples of cases brought on the grounds of industrial activities, see Australian Licensed Aircraft Engineers Association v International Aviations Service Assistance Pty Ltd [2011] FCA 333; Barclay v Board of Bendigo Regional Institute of TAFE [2011] FCAFC 14 (note this case was on appeal to the High Court at the time of writing).

${ }^{32}$ See for example Hammond v Boutique Kitchens and Joinery Pty Ltd [2010] FMCA 622 (application failed).
} 
the complaint in a conference had failed. ${ }^{33}$ When this happens, the complainant must decide (within 14 days $^{34}$ ) whether to take the matter further by making a 'general protections court application' to have the matter heard in the Federal Court or Federal Magistrates Court. Given the high cost of taking such proceedings, it is not surprising that few of these matters find their way to court. ${ }^{35}$ Many of the cases that have been pursued to a conclusion in litigation have been brought with the support of a trade union (and these tend to be the cases involving workplace rights or freedom of association issues rather than discrimination claims), ${ }^{36}$ or as a prosecution by the Fair Work Ombudsman. ${ }^{37}$

From a respondent employer's point of view, there is a clear incentive to refuse to agree to any settlement of a complaint in the conference held by Fair Work Australia (FWA). If the member conducting the conference takes the view that the application is unlikely to succeed, the member may 'advise the parties accordingly' under s 375, but there is no statutory provision requiring FWA to issue any advice to the effect that a matter has good prospects of success and ought to be conceded by the employer. Members do not always make recommendations as to the merits of cases during conferences, perhaps because they cannot speak with the same assurance about the likely outcome that they can in an unfair dismissal matter. ${ }^{38}$ FWA has no power to arbitrate these matters, so an employer can hold out and wait until the employee files a court application before seriously considering settlement options. The greatest risk that an employer runs in pursuing this strategy is the risk of a costs order, if the employee does have the resources to pursue and win a strong case, and if the Federal Court judge hearing the matter is

\footnotetext{
${ }^{33}$ Under Fair Work Act s 369, FWA must issue a certificate if 'all reasonable attempts to resolve the dispute have been, or are likely to be, unsuccessful'.

${ }^{34}$ See s 371(2). Extensions of time can be granted on the principles set down in Brodie-Hanns v MTV Publishing Ltd (1995) 67 IR 298.

${ }^{35}$ An austlii search of the Federal Court (FCA) and Federal Magistrates Court (FMCA) databases (on 20 April 2012) turned up no more than 12 FCA decisions and 42 FMCA decisions dealing with 'General Protections' since the commencement of the Fair Work Act. A number of these decisions related to the same complaints.

${ }^{36}$ See for example Australian Licensed Aircraft Engineers Association v International Aviations Service Assistance Pty Ltd [2011] FCA 333; Barclay v Board of Bendigo Regional Institute of TAFE [2011] FCAFC 14 (overturned by the High Court of Australia in [2012] HCA 42 (3 October 2012); Australian Licensed Aircraft Engineers Association v Qantas Pty Ltd \& Anor [2011] FMCA 58, [2012] FCAFC 63; Construction, Forestry, Mining and Energy Union v BHP Coal Pty Ltd [2010] FCA 590 (application failed).

${ }^{37}$ See for example Fair Work Ombudsman v Wongtas Pty Ltd (No 2) [2012] FCA 30; Fair Work Ombudsman v Drivecam Pty Ltd [2011] FMCA 600.

${ }^{38}$ [CITATION]MacDermott and Riley above $\mathrm{n}-\underline{8} 7$.
} 
minded to make an exceptional costs order under $s 570(2)$ on the basis that the employer behaved unreasonably in defending the matter.

So there is a clear if unascertainable risk that some meritorious claims will fail, simply because the procedure for pursuing the claim is too onerous for the individual complainant. Those who have the option of pursuing an unfair dismissal complaint instead may be well advised to do so. ${ }^{39}$ Many, however, do not have this avenue. The coverage of the general protections is significantly wider than the unfair dismissal protections. Employees whose employment is not covered by an award or enterprise agreement and who earn more than the high income threshold are not eligible for unfair dismissal protection. ${ }^{40}$ Nor are those who have not served the requisite minimum employment period. ${ }^{41}$ Casual employees who cannot establish a regular and systematic pattern of work and an expectation of continued employment on such a basis are also excluded. ${ }^{42}$ These exclusions do not apply to general protections claims. The general protections also cover 'prospective employees', so are capable of dealing with attempts to exclude people from entering the workforce on impermissible grounds. ${ }^{43}$ There is something paradoxical in this: the general protections are framed to cover a wider group than unfair dismissal because the interests protected are seen to be so fundamentally important, and yet the means for protecting those 'rights' are more inaccessible, at least to individuals who have not secured the support of a well-funded trade union nor attracted the sympathies of the Fair Work Ombudsman. ${ }^{44}$ To understand how this has come about, we need to review a little of the history

\footnotetext{
${ }^{39}$ Although presently, there are some significant limits on the remedies available in an unfair dismissal arbitration. If reinstatement is refused, compensation is capped at six months' salary, and there is no compensation for distress and humiliation: see Fair Work Act s 392. Compensation for a successful general protections claim is uncapped, and damages may be awarded for distress: see for example ALAEA v International Aviations Service [2011] FCA 333. Also, there is scope for any civil penalty awarded to be paid to the complainant, and this may assist in defraying costs of the application: see Fair Work Act s 546(3).

${ }^{40}$ See above $\mathrm{n} 65$.

${ }^{41}$ Fair Work Act s 383.

${ }^{42}$ Fair Work Act s 384(2).

${ }^{43}$ See Fair Work Act s 342(1) Item 2, and s 351(1)

${ }^{44}$ It is noteworthy that media reports are beginning to suggest that high net worth individuals are now using 'adverse action' claims to pursue multimillion dollar claims against employers. These are the kinds of litigants who can typically afford to use court processes, but they are often not the group that the legislation originally intended to benefit.
} 
of unfair and 'unlawful' dismissal protection in Australia, and the obstacle posed by the Boilermakers doctrine.

\section{UNFAIR v UNLAWFUL DISMISSAL}

The former Workplace Relations Act 1996 (Cth) framed two types of complaint about termination of employment: unfair dismissal, and unlawful dismissal. ${ }^{45}$ Each set of provisions was underpinned by separate constitutional powers. The unfair dismissal provisions were supported by the labour power, ${ }^{46}$ and also the corporations power, ${ }^{47}$ so they covered those employees whose conditions of employment had been determined as a consequence of some exercise of the powers for preventing or settling industrial disputes by conciliation or arbitration, and those who were employed by trading or financial corporations. (The Workplace Relations Act provisions, like the Fair Work Act provisions now, also excluded some categories of worker for policy reasons, and not just because of constitutional limitations. ${ }^{48}$ ) The unlawful dismissal provisions, however, were able to cover all employees (even those employed by unincorporated employers) because they were underpinned by the external affairs power. ${ }^{49}$ The Commonwealth's power to enact appropriate laws to give effect to the obligations assumed under international treaties was relied upon to enact into domestic law protections in tune with the International Labour Organisation's Termination of Employment Convention, 1982 (ILO C158). ${ }^{50}$ The first federal provisions to deal with individual rights to complain of unfair dismissal were enacted by the Keating government in the Industrial Relations Reform Act 1993 (Cth). These provisions were challenged by some states (lead by the Kennett government in Victoria) in Victoria $v$ Commonwealth, ${ }^{51}$ and the High Court of Australia found the provisions to be in excess of Commonwealth legislative power, to the extent that they purported to protect all Australian employees from dismissal that was merely capricious, and not contrary to the protections in ILO

\footnotetext{
${ }^{45}$ See Chapman above nn $\underline{3} z$ and 1716 for a full account of the Workplace Relations Act unfair dismissal provisions. ${ }^{46}$ Australian Constitution s 51(xxxv).

${ }^{47}$ Australian Constitution, s $51(\mathrm{xx})$.

${ }^{48}$ See Rosemary Owens and Joellen Riley The Law of Work (2007) 424-32 for a digest of the exclusions under the Workplace Relations Act. These exclusions were more extensive than those in the current legislation.

${ }^{49}$ Australian Constitution s 51(xxix).

${ }^{50}$ See Victoria v Commonwealth (1996) 187 CLR 416, 487. See also Koowarta v Bjelke-Petersen (1982) 153 CLR 168.

51 (1996) 187 CLR 416.
} 
C $158 .^{52}$ Consequently, the newly elected Howard government, in framing the Workplace Relations Act 1996 (Cth), separated 'unfair' from 'unlawful' dismissal by grounding the unfair dismissal provisions on those constitutional powers upon which it could rely without reference to ILO C 158 and the external affairs power.

Now that the Fair Work Act is based extensively on the corporations power and upon a reference of industrial matters from the States (except Western Australia), ${ }^{53}$ there is no constitutional reason for dividing unfair from unlawful termination of employment. Only those provisions in Pt 6-4 of the Fair Work Act (extending some termination of employment protections to non-national system employees) draw expressly upon ILO C $158 .{ }^{54}$ Commonwealth legislation could be enacted that dealt in the same way with both kinds of termination of employment capricious and harsh decisions on the one hand, and discriminatory decisions on the other without basing those provisions on notions of 'unlawfulness' drawn from the international law sphere. There is no reason why the kinds of dismissal prohibited by the general protections provisions could not also be framed as 'unfair' and dealt with as matters for resolution by a tribunal wielding administrative power. If the provisions avoid characterizing the protections as matters of legal right, they may avoid the trap set by the Boilermakers' doctrine.

\section{THE BOILERMAKERS' DOCTRINE}

The Boilermaker's doctrine - put simply - is that only courts can exercise the judicial power of the Commonwealth. ${ }^{55}$ This is the doctrine that was said to stand in the way of the Australian Labor Party's promises to create a 'One Stop Shop' in its Forward with Fairness policy documents,

52 (1996) 187 CLR 416, 510-521. For criticism of the High Court's decision in this respect, see Breen Creighton 'The Workplace Relations Act in International Perspective' (1997) 10 Australian Journal of Labour Law 31, 39-40.

${ }^{53}$ For an explanation of the constitutional basis of the Fair Work Act see Rosemary Owens 'Unfinished Constitutional Business: Building a National System to Regulate Work' (2010) 22 Australian Journal of Labour Law 258 and Andrew Lynch 'The Fair Work Act and the Referrals Power - Keeping the States in the Game' (2011) 24 Australian Journal of Labour Law 1.

${ }^{54}$ To the extent that there is a need for more inclusive provisions to protect employees who are outside the national system, the Fair Work Act contains Pt 6-4 (ss 771-783) to give effect to ILO C 158 and a number of other ILO Conventions for the benefit of non-national system employees, such any State and local government employees not covered by state referral agreements.

${ }^{55} R$ v Kirby; Ex parte Boilermakers' Society of Australia (1956) 94 CLR 254, 323 (Webb J), 296 (Dixon CJ, McTiernan, Fullager and Kitto JJ). See also Brandy v Human Rights and Equal Opportunity Commission (1995) 183 CLR 245, 2678 
released ahead of the 2007 federal election. ${ }^{56}$ It is the Boilermaker's doctrine that makes the distinction between an interests dispute and a rights dispute so important in our system of federal workplace laws. Interests disputes can be arbitrated by a body exercising administrative power - so long as we decide to legislate to confer upon a tribunal the power to create new rights. The traditional system for making industrial awards (abandoned with the introduction of the Work Choices laws from March $2006^{57}$ ) was a system by which the resolution of interests disputes (over the terms and conditions that ought to govern certain occupational employment) created new rights (i.e. the terms of awards). Rights disputes, however, concern the application and interpretation of existing legal entitlements, and must be resolved by a court exercising judicial power, unless the parties themselves have entered into a contract to permit some other form of dispute resolution. Such a contract is a private arbitration agreement, and will be enforceable depending upon prevailing State law. ${ }^{58}$

The Boilermaker's doctrine has influenced the choice of dispute resolution processes for unfair dismissal and general protections applications. Unfair dismissal applications go to an administrative tribunal (FWA) for conciliation and if that fails, arbitration, because an unfair dismissal application is treated as a plea for the creation of a new right to reinstatement. ${ }^{59}$ The administrative decision-maker is charged with the duty to weigh up the competing interests of employer and employee, and possibly others at the workplace, before making a decision that balances these interests, and achieves a 'fair go all round'. On the other hand, we think of general protections claims as an assertion of an existing legal entitlement to be free from victimization when we are exercising workplace rights, including our right to participate in the workforce free of discrimination on irrelevant grounds. The decision maker determining our claim must exercise judicial power in determining whether any such right has been infringed. So long as general protections claims are conceived as assertions of legal rights, the appropriate decision maker is a court exercising judicial power. Unfortunately, except perhaps in the case of urgent

${ }^{56}$ Kevin Rudd and Julia Gillard Forward with Fairness - Policy Implementation Plan, ALP, August 2007.

57 See Workplace Relations Amendment (Work Choices) Act 2005 (Cth).

${ }^{58}$ See Andrew Stewart and Joellen Riley 'Working Around Work Choices: Collective Bargaining and the Common Law' (2007) 31 Melbourne University Law Review 903, 927-36

${ }^{59}$ In reality, more claims result in an award of compensation, which may be made if FWA has determined that reinstatement is not appropriate in all the circumstances: Fair Work Act s 390(3). 
interlocutory injunctions, courts do not deal with matters quickly nor inexpensively, so court proceedings are rarely the most efficient means for dealing with claims from individual employees that they have been subjected to discriminatory treatment at work. ${ }^{60}$

Of course some will argue that efficiency is a lower order concern than justice in these cases, and justice demands a guarantee that these matters will be determined as a matter of legal right by a tenured and independent judicial officer, assisted by argument from counsel, and after rigorous testing of evidence. ${ }^{61}$ The following argument proceeds on the assumption that it is better to tolerate a rougher form of justice, if it permits access to appropriate remedies for those applicants who may well be excluded by the existing court justice system.

The inefficiency of current court process as a means for resolving many kinds of disputes has been recognized in the passage of the Civil Dispute Resolution Act 2011 (Cth). This legislation recognizes that disputes ought not to be litigated unless the parties really have attempted every available means to resolve the matter more efficiently, and so it requires parties to take 'genuine steps' to resolve disputes before instituting civil proceedings. 'Genuine steps' includes 'considering whether the dispute could be resolved by a process facilitated by another person including an alternative dispute resolution process' ${ }^{62}$ (Actions brought under the Fair Work Act are exempted from this obligation, ${ }^{63}$ no doubt because the Fair Work Act already requires parties to attempt to settle a complaint in a compulsory conference.$^{64}$ ) So even in matters involving legal rights, our legal system has recognized the inefficiency of litigation as a means of dispute resolution.

The alternative dispute resolution methods encouraged by the Civil Dispute Resolution Act need not be merely a preliminary to litigation. In the case of the 'rights' protected by the Fair Work general protections, alternative dispute resolution by an administrative tribunal could

\footnotetext{
${ }^{60}$ See Smith above $\mathrm{n} 2419,574$.

${ }^{61}$ Arbitrations before FWA typically follow a court-like procedure for calling upon and testing evidence in any case, but applicants do not need to be represented, and the tribunal is charged with dealing with matters according to equity, good conscience and the substantial merits of the case without regard to legal technicalities.

${ }^{62}$ Civil Dispute Resolution Act s 4(1)(d).

${ }^{63}$ Civil Dispute Resolution Act s 16(d).

${ }^{64}$ Where a general protections claim is brought by a person whose employment has not been terminated, the conference conducted by FWA is not compulsory: see Fair Work Act s 372.
} 
provide a complete replacement for litigation, so long as these general protections were appropriately framed in the statute. This would require a reassessment of the conception of general protections as rights, and creation of a new model for their protection. We might draw a clue from another field of law - the regulation of corporate mergers and acquisitions - in devising such a model.

\section{THE TAKEOVERS PANEL CASE}

According to the High Court in Attorney-General of the Commonwealth of Australia $v$ Alinta Limited (the Takeovers Panel Case), ${ }^{65}$ it is appropriate for parliament to confer a dispute resolution role on a body exercising non-judicial power whenever resolution of that dispute requires the consideration of matters of public policy.

The Takeovers Panel Case concerned a challenge to the constitutional validity of legislation conferring powers on the Takeovers Panel to determine whether parties involved in hostile takeovers of public companies had engaged in unacceptable conduct. ${ }^{66}$ For example, if a company shareholder who had mounted a hostile takeover of the company was aggrieved that the directors of the company had issued new shares to a party friendly to the directors' views, it would be the Takeovers Panel which would convene promptly to consider whether the directors' conduct constituted 'unacceptable circumstances' and warranted a remedial order, such as an order cancelling the new shares. ${ }^{67}$

In the olden days, before the institution of the Takeovers Panel, parties challenging directors' conduct in such circumstances would need to bring a suit in the Supreme Court, complaining of a breach of the directors' fiduciary duty to exercise their powers only in good faith, in the best interests of the company and for a proper purpose. ${ }^{68}$ The sheer delay involved in litigating such a matter would be likely to favour the directors' position, notwithstanding that

65 [2008] HCA 2

${ }^{66}$ For a discussion of the issues in the case written prior to the decision, see Emma Armson 'Attorney-General (Commonwealth) v Alinta Limited: Will the Takeovers Panel Survive Constitutional Challenge?' (2007) 29 Sydney Law Review 495.

67 See Corporations Act 2001 (Cth) s 657A and definition of 'remedial order' in s 9.

${ }^{68}$ See for example Howard Smith Ltd v Ampol Petroleum Ltd [1974] AC 821 
the matter would be likely to proceed first as an application for an interlocutory injunction. The court proceedings would effectively freeze the progress of the takeover bid to the detriment not only of the bidder, but also of those wishing to accept the bid. The Takeovers Panel was instituted to confer the resolution of these kinds of contests upon specially appointed experts in the market for securities, who would be charged with the responsibility of serving the public interest in maintaining an 'efficient, competitive and informed market' for corporate securities. ${ }^{69}$ On the view of those challenging the legislation, the legislation permitted the Panel to exercise judicial power, because it was able to make remedial orders which potentially affected people's rights. The High Court held, however, that the Panel was playing a supervisory and regulatory function, and pursuing the public interest in ensuring efficiency and fairness in the market for listed securities. Its exercise of its powers created 'new rights and obligations ${ }^{70}$ and did not 'simply determine conclusively (as a court might do) controversies over past suggested contraventions of the Act' ${ }^{71}$ It was important to the findings in this case that decisions of the Takeovers Panel could themselves be scrutinized and subjected to judicial review under $s 75(\mathrm{v})$ of the Constitution, ${ }^{72}$ and the enforcement of the Panel's orders remained with the courts.

\section{FAIR WORK AUSTRALIA'S ROLE}

On one view, Fair Work Australia (FWA) is doing similar work for the labour market as the Takeovers Panel does for the market for corporate control. The objects of the Fair Work Act (in s 3) assert an overarching goal of providing 'a balanced framework for cooperative and productive workplace relations that promote national economic prosperity and social inclusion for all Australians'. 'Social inclusion' is a broad policy, which is served in part by the general protections provisions supporting the entitlement of workers to challenge their exclusion from the workplace for impermissibly discriminatory reasons. Already, the provisions prohibiting dismissal on the grounds of race, colour, sex, etc, ${ }^{73}$ are moderated by some defences. One of

\footnotetext{
${ }^{69}$ See Corporations Act s 602(a). See also The Takeovers Panel Case [2008] HCA 2, [6].

70 Per Gleeson CJ, [2]; Gummow J, [14]; Kirby J, [42].

${ }^{71}$ Per Kirby J, [42].

72 The Australian Constitution s 75(v) provides that the High Court of Australia has original jurisdiction to grant a

writ of mandamus, prohibition or injunction against an act of an officer of the Commonwealth.

${ }^{73}$ The full list of protected characteristics in s 351(1) is listed above $n \underline{29} 24$.
} 
these is the defence that the discriminatory action was taken 'because of the inherent requirements of the particular position concerned'. ${ }^{74}$ Another is the defence available to religious institutions who make discriminatory decisions 'in good faith' and 'to avoid injury to the religious susceptibilities of adherents to that religion or creed' ${ }^{75}$

There are two ways of conceptualizing the operation of these defences. On one view they clarify the extent of the employee's right. It is a right to be free from exclusion on irrelevant discriminatory grounds. If the grounds upon which the employer has discriminated are relevant to whether the employee can perform the inherent requirements of the job, or if they are relevant to whether employing the employee will compromise the religious values of the enterprise, then the employee has no right against discrimination. On another view, the defences indicate that, although the employee is entitled to protection from discrimination, that entitlement may be compromised by the employer's competing interest in efficient accomplishment of the work, and in the preservation of religious values. The first view engages the discourse of rights, the second a narrative about negotiation over interests. From the aggrieved employee's perspective, it doesn't matter much which view is adopted. Both lead to the same contest over which prevails - the employee's right/entitlement, or the employer's interest. The advantage of the second characterization of the contest as a dispute over interests is that it permits the choice of an administrative tribunal to deal with the matter, not only by holding a preliminary conference, but by finally arbitrating the matter. Conferences held in the shadow of potential arbitration in a short time, by the same tribunal, are more likely to focus the minds of participants on reasonable settlement. ${ }^{76}$

If there is a practical benefit for complainants in managing these disputes as interests disputes before a tribunal, then it is certainly worth investigating ways of framing the employee's entitlement to contest a discriminatory dismissal as an interest, rather than a hard-edged legal right. How might this be done? The simplest way to achieve a consolidation of the provisions dealing with both discriminatory and capricious dismissal would be to include a new subsection

${ }^{74}$ Fair Work Act s 351(2)(b).

${ }^{75}$ Fair Work Act s 351(2)(c).

${ }^{76}$ [CITATION] MacDermott and Riley above $\mathrm{n} \underline{87}$. 
in FW Act s 385, 'What is an unfair dismissal', that makes any dismissal for a reason including any of the reasons presently listed in s 351(1) presumptively 'unfair'. The reversed onus of proof could be maintained, so that any FWA member ultimately arbitrating a complaint should be required to be satisfied that the employer had established that the required 'valid reason' for dismissal had not been compromised by any other, impermissibly discriminatory reason. The inherent requirements of the job, and appropriate adherence to religious sensibilities, could be treated as matters that FWA should take into account in determining how best to accord a 'fair go all round' in all the circumstances of the matter. The provisions in s 392 on remedies could stipulate that compensation orders could take account of shock, distress and humiliation in circumstances where the relevant unfairness included discriminatory treatment, and compensation in respect of these kinds of injury could be treated as additional to any compensation for loss of the job, which is presently capped at six months' salary for unfair dismissal claims.

Although this proposal would permit FWA to arbitrate contested applications for discriminatory dismissal in the same way as it presently arbitrates unfair dismissal applications, there would still be a role for the courts in enforcing FWA's orders, and in judicially reviewing FWA decisions on administrative law grounds, just as is presently the case with unfair dismissal

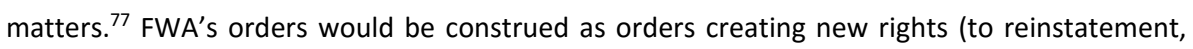
compensation, or possibly to a new right of a published apology or other remedy appropriate to the particular kind of indignity inflicted upon the worker). Courts exercising judicial power would still be called upon to enforce the rights and obligations attaching to FWA orders. ${ }^{78}$

\section{ADVANTAGES}

The advantage of these arrangements for applicants would be that the same expert tribunal who hears unfair dismissal claims would also be able to arbitrate discriminatory dismissal claims. Preliminary conferences attempting to mediate a solution to complaints would occur in the shadow of potential arbitration by a FWA member in a relatively short period of time. This may

\footnotetext{
${ }^{77}$ See for example Damevski v Giudice (2003) 133 FCR 438; Visscher v Giudice (2009) 239 CLR 361

${ }^{78}$ See Takeovers Panel case, [7].
} 
better focus the minds of the parties on reaching a reasonable settlement of the claim. It would take away any incentive for employers to resist all negotiations of settlement on the assumption that the complainant will not have the means nor the fortitude to pursue the complaint through the federal court system. Employees who have won an order from FWA may still face some challenge to that order by way of an application for judicial review, but the employer will bear the onus of proving some manifest error in FWA's exercise of its discretion. Unmeritorious claims will be picked up earlier in the system. Quicker resolution of complaints may avoid the risk that long running litigation may create its own oppressive psychological burden on a vulnerable individual.

A further advantage is that more decisions may build more rapidly a body of instructive jurisprudence to encourage better compliance with equality norms in workplace. (The FWA decisions database shows that there are many more unfair dismissal decisions than there are federal court judgments on discrimination at work.) One of the complaints Belinda Smith makes about the current regime of anti-discrimination laws more generally is that they are "backward focused and individualistic rather than preventative and systemic' ${ }^{\prime 79}$

\section{CONCLUSION}

Some readers may object to the basic premise of this paper, that we should surrender up the discourse of 'workplace rights' in the case of discriminatory dismissals, with a view to securing a more pragmatic and efficient system for dealing with such complaints. Certainly, there are ideological and philosophical reasons for claiming equality 'rights', but there is a risk that rights will prove nothing more than 'paper tigers, fierce in appearance, but missing in tooth and claw', ${ }^{80}$ if the system is not able to provide accessible avenues for recognition and enforcement of those rights. There is sometimes a romantic vision of the champion of rights, battling for justice in the court system and emerging triumphantly with a valuable precedent to be shared for the benefit

${ }^{79}$ See Smith above $\mathrm{n} 2419,574$

${ }^{80}$ Bob Hepple and Gillian Morris, 'The Employment Act 2002 and the Crisis of Individual Employment Rights' (2002) 31 Industrial Law Journal 245, 247. 
of all. In reality, the court system itself sometimes perpetrates the victimization of the weak, not because any member of legal profession, court administration system or judiciary intends to do so, but because the wheels of justice are oppressively heavy for the average working person. Ordinary people can be ground down and made physically sick by the processes of justice. One needs to be remarkably robust, and well-supported financially, to survive the ordeal. A more compassionate system would ensure that the victims of workplace discrimination had a gentler, quicker and cheaper path to a satisfactory resolution of the complaint. That is more likely to occur through compulsory conciliation and arbitration before FWA than by taking the path to court.

According to the discrimination law scholars, the results from the court cases are often disappointing in any event, and do not produce the precedents to hoist up as exemplars for business and industry. ${ }^{81}$ If that is so, it is perhaps time to investigate an alternative model for dealing with discrimination at work. Engaging the existing institutional framework of FWA seems a sensible and worthwhile experiment.

${ }^{81}$ See above $n \underline{24202019}$. 